\title{
The Effect Of Human Resource Investment In Internal Accounting Control On Cost Stickiness
}

\author{
Soo-Joon Chae, Ph.D., Kangwon National University, South Korea
}

Kiwi Chung, Ph.D., Yeungnam University, South Korea

\begin{abstract}
This study examined the characteristics of internal accounting control system based on size of human resources assigned to the system to verify whether downward stickiness of total cost and selling and administrative expenses differentially appears according to the level.

An entrepreneur who wishes to maximize one's utility has an incentive to externally grow the enterprise beyond the optimal size or to possess idle resources, creating cost sticking phenomenon by possessing surplus resources even when sales volume decreases. Previous studies verified the effect of control system intended to resolve the agency problem on asymmetry of cost. This study expanded the scope of previous studies to consider internal accounting control system as a monitor of the agency problem. Enterprises that effectively operate internal accounting control system are expected to show limited opportunistic incentive of the entrepreneurs because of reduced agency cost.
\end{abstract}

The main purpose for enterprises to establish and operate internal accounting control system is to provide accurate and reliable financial information to investors by preventing or uncovering accounting scandals of the management and possibility of errors. Internal accounting control system of Korea was first introduced in September 2001 through 'Corporate Restructuring Promotion Act', and Financial Supervisory Service announced the regulation on public announcement in September 2002 as a series of relevant measures. The regulation requires enterprises to publicly announce the number of workers in each department in charge of internal accounting control system on the internal accounting control system report. Under the presumption that internal accounting control can be more effectively done by increasing the number of workers in charge of internal accounting control system, the intent of such public announcement is to provide external interested parties with information that can be used to determine whether internal accounting control system of an enterprise is being effectively managed. Accordingly in this study, enterprises with large size of human resources assigned to internal accounting control system were predicted to show relaxed downward stickiness of cost.

As a result of verifying 2,532 enterprise-year samples listed on Korea Stock Exchange between 2003 and 2008, enterprises with larger size of human resources assigned to internal accounting control system were found to show relaxed downward stickiness of cost. This means that an enterprise with large number of workers assigned to internal accounting control system can effectively monitor the enterprise, which can efficiently control opportunistic decisions of the entrepreneur such as downward stickiness of cost. As an additional analysis, human resources were classified into departments to which persons in charge of internal accounting are affiliated to examine the effect on downward stickiness of cost. As a result of verification, high ratio of internal accounting personnel assigned to accounting department resulted in relaxed downward stickiness of cost. Accounting departments in charge of preparing for financial statements were more effectively performing monitoring work compared to other departments.

Keywords: Internal Accounting Control System; Human Resource Characteristics; Downward Stickiness of Cost Copyright by author(s); CC-BY 


\section{INTRODUCTION}

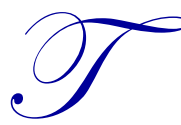

his study analyzed the effect of human characteristics of internal accounting control system on asymmetric cost behavior of enterprises. In specific, effectiveness of internal accounting control system was examined by size of human resources assigned to internal accounting control system, empirically verifying whether asymmetric cost behavior of an enterprise is differentiated by the level of internal accounting control system.

Traditional cost model assumed that cost shows symmetric behavior regardless of increase and decrease in operating rate (Noreen 1991). However, an argument was proposed (Cooper and Kaplan 1998) that cost shows downward sticky behavior because it is more difficult to reduce cost when activity level is reduced than to increase cost when activity level is increased. Previous studies conducted at home and abroad including the study of Anderson et al. (2003) report downward sticky behavior of cost. Specifically, Anderson et al. (2003) verified that the change in cost differs when activity level of an enterprise increases and decreases, pointing out the agency problems such as pursuit of private benefit and utility by the entrepreneur as a cause of downward sticky behavior. In other words, since reducing size of the organization or dismissing an employee who shares the same interest brings damages the personal dignity of the entrepreneur, the entrepreneur has an incentive to not actively reduce surplus resources when sales volume decreases. Chen et al. (2012) also presented a view that empire-building tendency and perquisite consumption of entrepreneurs induce downward sticky behavior of cost. On one hand, subsequent studies verified diverse effects of corporate governance structure on downward stickiness of cost under the judgment that opportunistic incentives of an entrepreneur are limited by reduced agency cost in an enterprise with effective control structure because it has high efficiency of monitoring.

This study paid attention to internal accounting control system as a monitor to control downward stickiness of cost resulting from opportunistic incentives of an entrepreneur. The purpose of internal accounting control system is to control errors and corruptions in accounting information among various intents of internal control, and to prepare and publicly announce reliable accounting information through regular inspection and adjustment of accounting information. Accordingly, this study attempted to examine whether internal accounting control system introduced as a means to control errors and corruptions in accounting information performs the role of a monitor in lessening the agency problem of an enterprise. Specifically, effectiveness of internal accounting control system was examined by size of human resources assigned to internal accounting control system, analyzing whether downward stickiness of cost is shown differently according to the level.

In the United States, large-scale accounting scandals of Enron and World Com which occurred during early 2000 s presented the need to establish and reinforce a system for monitoring corruption of entrepreneurs. An accounting reform law called Sarbanes-Oxley Act (SOX) was legislated in 2002. Article 404 of SOX requires the management of a company to establish and evaluate internal control measure to improve quality of financial statements, while at the same time demanding external auditor to review appropriateness of such internal control. Such measure shows that establishment of an appropriate internal accounting control system is an essential condition to improve reliability of accounting information. To establish internal accounting control system for increased reliability of accounting information, Korea has temporarily included regulation on internal accounting control system in the Corporate Restructuring Promotion Act in 2001. At the 16th regular meeting of Financial Supervisory Commission, internal accounting control system operation report was revised in the [Regulation on Financial Supervisory Agencies for Corporate Restructuring Promotion] to require enterprises to additionally announce the current status of internal accounting control organization and certified public accountants, starting with the business reports of enterprises settling their accounts in December 2002.

On one hand, information about size of human resources in charge of internal accounting control system is only publicly announced in Korea. The reason for regulatory institutions to force public announcement of this information is to offer external interested parties with the grounds to judge the effectiveness of internal accounting control system of an enterprise. That is, this regulation reflects the expectation that enterprises placing greater investment on internal accounting personnel are more effectively operating their internal accounting control system. Therefore, it is necessary to verify how effectiveness of monitoring is differentiated according to size of internal accounting personnel. Accordingly in this study, effectiveness of internal accounting control system was examined 
by size of human resources in charge to find the effect of effective operation of system on opportunistic decisions of entrepreneurs. An entrepreneur has a tendency to maintain surplus resources when sales volume is reduced because of one's empire-building tendency and perquisite consumption, and maintenance cost involved with such tendency reduces quality of financial statements as a product of agency problem.

Conclusions and contributions of this study are as follows. First, this study considered internal accounting control system as a monitor of agency problems. Effectiveness of internal accounting control system can be examined by size of human resources assigned to internal accounting control system. Larger size of human resources was predicted to show higher efficiency of monitoring on decisions of entrepreneurs. As a result of analysis, enterprises with large size of human resources showed more elastic reduction of cost with decrease in sales volume. The result verified that sufficient number of internal accounting personnel allows for appropriate distribution of work and timely review and monitoring of decision making by entrepreneurs, resulting in effective internal control.

This study consists of the following. Chapter II introduces theoretical background, summarizes previous studies and sets forth the hypothesis of this study. Chapter III explains the process of selecting samples used for testing of the hypothesis and study model. Chapter IV explains the results of empirical analysis, and Chapter V summarizes the conclusions and contributions of this study.

\section{LITERATURE REVIEW AND HYPOTHESES}

\section{Literature Review}

Ever since SOX of the United States specified details of internal accounting control system, many studies were conducted on internal accounting control system. Previous studies used vulnerability report as an alternative value to examine operating condition of internal accounting management system.

First, companies with vulnerabilities to internal accounting control system were analyzed in comparison to companies without vulnerabilities. Ashbaugh-Skaife et al. (2007) discovered that enterprises reporting vulnerabilities in internal control had more complex business activities, recent change in the organization, more frequent replacement of external auditor, and small amount of resources used to operate internal control compared to enterprises that did not report vulnerabilities. Doyle et al. (2007a) reported that enterprises showing important vulnerabilities were small, newborn, financially weak, in high growth and under restructuring. Also, Ge and McVay (2005) argued that important vulnerabilities result from assignment of insufficiently trained accounting personnel. Krishnan (2005) mentioned that low quality of audit committee measured by size, independence and expertise is highly correlated to discovery of important vulnerabilities.

There are studies that investigated the relationship between vulnerabilities of internal accounting control system and earnings quality. As a result of examining discretionary accruals, mean accruals, rewriting of financial statements in the past, and earnings persistence as alternative values of earnings quality, Doyle et al. (2007b) reported that earnings quality of companies with important vulnerabilities in internal control is lower than earnings quality of companies without vulnerabilities. Ashbaugh-Skaife et al. (2008) reported that enterprises reporting vulnerabilities in internal control show lower quality of accruals compared to other enterprises, and those enterprises improving such vulnerabilities show increased quality of accruals compared to enterprises that do not improve vulnerabilities.

Meanwhile, existing studies examined the level of internal accounting control system based on existence of vulnerabilities in internal accounting control system. This means that enterprises reporting vulnerabilities have low effectiveness of internal accounting control system and enterprises without vulnerabilities are effectively operating internal accounting control system. However, since effectiveness of system can be shown differently among enterprises that do no report vulnerabilities according to characteristics of human resources, there is a limit to determining effectiveness of internal accounting management system simply based on reporting of vulnerabilities. 
Information about size of human resources in charge of internal accounting control is not publicly announced in countries other than Korea. Thus, there is lack of studies on size of human resources in charge of internal accounting control. Nonetheless, since effective operation of internal accounting control system depends on human resources in charge of internal accounting, size of human resources in charge of internal accounting control can be useful information for external information users in examining effectiveness of internal accounting control system for a specific enterprise.

Ge and McVay (2005) mentioned 'lack of qualified accounting personnel' as the foremost reason for ineffectiveness of internal control. Choi et al. (2011) analyzed the effect of investment in human resources in charge of internal accounting control system on existence of vulnerabilities in internal accounting control system and earnings quality. They discovered the fact that enterprises with greater investment on human resources in charge of internal accounting control system show higher earnings quality because possibility of vulnerabilities in internal accounting control system is reduced and earnings management measured as discretionary accruals is reduced. As such, enterprises that fail to secure sufficient internal accounting control personnel do not have enough personnel to operate internal accounting control system, showing relatively low effectiveness of internal control. In other words, such enterprises are less likely to have sufficient monitoring function to prevent and uncover errors or corruptive acts of entrepreneurs that can damage reliability of financial statements. Ultimately, enterprises that do not have sufficient human resources to operate internal accounting control system can be predicted to have higher possibility of accounting scandals compared to other enterprises.

\section{Hypothesis Development}

Traditional cost accounting assumed (Noreen 1991) proportionality of cost behavior in which change of cost is proportional to changes in operating rate and activity level, but recent studies are providing empirical evidences on asymmetry of cost behavior which are contrary to proportionality of cost behavior. As mentioned earlier, an entrepreneur who wishes to maximize one's utility has an incentive to externally grow the enterprise larger than its optimal size or to possess idle resources. Such entrepreneur causes fixing of cost by possessing surplus resources when sales volume is decreased. Downward stickiness of cost behavior caused by adjustment cost and agency cost seems to be a result of discretionary power of entrepreneurs, and such phenomenon appears as a result of decision making by entrepreneurs (Anderson et al. 2003). Therefore, a control system that monitors the decision making process of an entrepreneur can affect asymmetry of cost behavior (Chen et al. 2012).

This study aims to consider internal accounting control system as a monitor to control downward stickiness of cost resulting from opportunistic incentives of an entrepreneur. Size of human resources assigned to internal accounting control is to be considered in this study as a variable to examine effectiveness of internal accounting control system. Sufficient number of internal accounting personnel means that internal accounting control work is distributed appropriately with timely review and monitoring on accounting functions. In other words, enterprises that make large investment on human resources of internal accounting control system can effectively perform internal control and show excellent quality of internal accounting control system (Choi et al. 2009). Therefore in this study, larger size of human resources in charge of internal accounting control system is predicted to show effective control of opportunistic decision making by entrepreneurs. That is, a negative (-) correlation will be shown between the number of human resources in charge of internal accounting control system and downward stickiness of cost. The first hypothesis is formulated as follows.

Hypothesis: Larger size of human resources assigned to internal accounting control system will lessen downward stickiness of cost.

\section{Selection of Samples and Study Methodology}

\section{Selection of Samples}

This study selected enterprises listed in the stock market between 2003 and 2008 that satisfy the following requirements as samples. Samples were limited to enterprises settling their accounts at the end of December in order to secure timely homogeneity of data. In addition, enterprises that belong to the financial industry were excluded 
from samples because they have different items and meanings of financial statements compared to general enterprises. Additionally, 982 enterprise-year samples were excluded in case financial data could not be collected or problem occurred during measurement of downward stickiness. Also, Winsorization was performed on top 1\% and bottom 15 of variables used in the empirical analysis to control the effects of values. 2,532 enterprise-year were selected as final samples according to the conditions described above.

Table 1. Compositions of Samples

\begin{tabular}{lc}
\hline \multicolumn{1}{c}{ Category } & Sample Size \\
\hline $\begin{array}{l}\text { Enterprise-year samples listed in the stock market between 2003 2008 } \\
\text { (Excluded) enterprise-year samples that do not settle their accounts in December or that belong to the } \\
\quad \text { financial industry }\end{array}$ & 4,638 \\
$\begin{array}{l}\text { (Excluded) financial data could not be obtained or problem occurred during measurement of downward } \\
\text { stickiness of cost }\end{array}$ & $(1,124)$ \\
Enterprise-year samples used in the analysis & $(982)$ \\
\hline
\end{tabular}

\section{Measurement of Cost Asymmetry}

In this study, downward stickiness of cost was measured using the method of Weiss (2010). Existing studies mainly used the model of Anderson et al. (2003) to measure cost behavior. The model of Anderson et al. (2003) cross-sectionally defines downward stickiness as a phenomenon in which the rate of increase in cost with increase in sales is larger than decrease in cost with decrease in sales. This model had a limitation in measuring changes in cost against change in sales for individual enterprises. Accordingly in this study, the model of Weiss (2010) that can measure downward stickiness of cost for individual enterprises was utilized. Weiss (2010) directly measured the difference between the rate of increase in cost with increase in sales and the rate of decrease in cost with decrease in sales on the level of individual enterprises, and defined this difference as downward stickiness of cost. Specific measurement method is as follows.

$$
\begin{array}{cl}
\operatorname{STICK} Y_{i t} & =\log \left(\frac{\Delta \text { cost }}{\Delta \text { sales }}\right)_{i \gamma}-\log \left(\frac{\Delta \text { cost }}{\Delta \text { sales }}\right)_{i \mu} \quad \gamma, \mu \in\{t, \ldots, t-3\} \\
S T I C K Y_{i t} & : \text { downward stickiness of cost for term } \mathrm{t} \text { of enterprise } \mathrm{i} \\
\gamma & : \text { quarters during which sales decreased among recent } 16 \text { quarters } \\
\mu & : \text { quarters during which sales increased among recent } 16 \text { quarters } \\
\Delta \text { sales }_{i t} & : \text { change in sales of enterprise i for term } \mathrm{t} \quad\left(\operatorname{sales}_{i t}-\text { sales }_{i t-1}\right) \\
\Delta \operatorname{cost}_{i t} & : \text { change in cost of enterprise i for term } \mathrm{t} \quad\left(\operatorname{cost}_{i t}-\operatorname{cost}_{i t-1}\right)
\end{array}
$$

Weiss (2010) defined downward stickiness of cost (STICKY) for individual enterprises as the difference between the rate of decrease in cost with decrease in sales of the recent quarters and the rate of increase in cost with increase in sales of the recent quarters. According to the method used by Weiss (2010), this study also measured STICKY variable for 16 quarters by subtracting the slope of cost function for the recent quarters during which sales have increased from the slope of cost function for the recent quarters during which sales have decreased. If cost is downward sticky, the degree of reduction in cost with decrease in sales is smaller than the degree of increase in cost with increase in sales. STICKY will have a negative (-) value. Furthermore, when the value of STICKY is measured to be 0 , it represents a symmetric cost behavior. When the value of STICKY is larger than 0, it refers to a downward elasticity of cost. For ease of interpretation on empirical analysis in this study, the value obtained by multiplying STICKY with (-1) was used as the alternative value.

\section{Asymmetry Measurement of Human Resources in Charge of Internal Accounting Control System}

Current status of internal accounting control organization personnel and certified public accountants has been publicly announced as an attachment to the business reports called "operating report on internal accounting 
control system" since 2002. In this study, size of personnel assigned to internal accounting control system was examined through "operating report on internal accounting control system" to find the effect of human resource characteristics of internal accounting control system on downward stickiness of cost.

\section{Research Model}

This study attempts to verify the change in downward sticky behavior according to human resources of internal accounting control system. Using IC as a dependent variable for the number of human resources assigned to internal accounting control system, an independent variable, dummy variable (STICKYD1) for downward stickiness of cost measured by selling and administrative expenses and dummy variable (STICKYD2) for downward stickiness of cost measured by total cost were set forth. IC was measured as a value obtained by taking natural $\log$ on the number of human resources assigned to internal accounting control system. Control variables included conglomerate (GROUPD), asset intensity of enterprise (SIZE), employee intensity (WORKER), cash flow for operation (CFO), consecutive reduction of sales for two years (SALES) and debt ratio (LEV). First, according to the study of Anderson et al. (2003) which mentioned that adjustment cost needed for an entrepreneur to reduce resources increases with increasing asset intensity, asset intensity (SIZE) was included as a control variable. In addition, since a labor-intensive enterprise that requires human resources for sales experiences adjustment cost when sales increases after reducing surplus personnel due to decrease in sales, employee intensity was included as a control variable to consider the effect of employee intensity on downward stickiness of cost. As enterprises with high cash flow ratio or liquidity have greater ability to maintain surplus resources with decrease in sales, previous study (Anderson et al. 2003) suggested that downward stickiness of cost becomes relatively stronger. Cash flow for operation (CFO) computed by dividing cash flow from operating activities by total asset was considered as a control variable. Lastly, consecutive reduction in sales for two years (SALES) was taken into account as a control variable. When profit of enterprises decreases for two consecutive years, entrepreneurs have an incentive to judge that demand will be reduced in the long term and decide to reduce cost according to decrease in sales (Chen et al. 2012).

STICKY $_{i t}=\beta_{0}+\beta_{1} I C_{i t}+\beta_{2}$ GROUPD $_{i t}+\beta_{3}$ SIZE $_{i t}+\beta_{4}$ WORKER $_{i t}+\beta_{5}$ CFO $_{i t}+\beta_{6}$ SALES $_{i t}+\beta_{7} L_{E V}+\epsilon_{i t}$

STICKYD1 : dummy variable for downward stickiness of cost scaled by selling and administrative expenses, 1 if sticky $<0,0$ otherwise

STICKYD2 : dummy variable for downward stickiness of cost scaled by total cost, 1 if sticky $<0,0$ otherwise

IC $\quad: \ln$ (=number of personnel of internal accounting)

GROUPD $\quad: 1$ if the enterprise belongs to a conglomerate, 0 otherwise

SIZE $\quad: \ln$ (total asset of current term/total sales of current term)

WORKER : (number of employees*1,000,000/total sales of current term)

CFO : (Cash flow from operating activities of the current term/ total asset of the current term)

SALES $\quad: 1$ if sales of term $\mathrm{t}-1$ is decreased compared to term $\mathrm{t}-2,0$ otherwise

LEV : (total debt of the current term/total asset of the current term)

\section{EMPIRICAL RESULTS}

\section{Descriptive Statistics and Correlation Analysis}

Table 2 summarizes descriptive statistics of major variables used to test the hypothesis of this study. First, the variable IC that represents the number of human resources assigned to internal accounting control system was measured as a natural $\log$ value. The mean value of 2.682 , which corresponds to 14.6 employees per enterprise assigned to internal accounting control system when converted to the number of persons. Dummy variable STICKYD1 is a variable for downward stickiness of cost measured by selling and administrative expenses 
according to Weiss (2010), and the value of this variable is 1 when it represents a negative $(-)$ value and 0 otherwise. STICKYD2 is also a dummy variable that measures downward cost stickiness of Weiss (2010) based on total cost. The value of this variable is 1 when it represents a negative $(-)$ value and 0 otherwise. In other words, enterprises that show downward sticky cost behavior are granted with a value of 1 for dummy variables. The mean values (median values) of STICKYD1 and STICKYD2 were found to be 0.194 (0) and 0.368 (0), respectively. STICKY1 is a value that multiplied (-1) with the continuous variable for downward cost stickiness of Weiss (2010) measured by selling and administrative expenses. STICKY2 is a value that multiplied (-1) with the continuous variable for downward cost stickiness of Weiss (2010) measured by total cost. Therefore, larger positive (+) values of STICKY1 and STICKY2 can be interpreted as greater downward stickiness of cost behavior. The mean (median) values of these variables were respectively $0.178(0.175)$ and $0.224(0.135)$, showing positive $(+)$ values. The majority of enterprises were confirmed to have downward sticky behavior of cost. The mean (median) value of asset intensity variable SIZE was 1.634 (1.095), and its maximum and minimum values were 16.891 and 0.324 . This shows a great difference in asset intensity between enterprises. The mean (median) value of employee variable WORKER was 0.003 (0.002), and the mean (median) value of cash flow variable for operating activities of the current term CFO was $0.052(0.088)$. The mean (median) value of dummy variable on reduction of sales for term t-1 compared to term t-2, SALES, was $0.239(0.000)$. Only $24 \%$ of enterprises showed reduction in sales during term t-1 compared to term $\mathrm{t}-2$.

Table 2. Descriptive Statistics

\begin{tabular}{lccccc}
\hline \multicolumn{1}{c}{ Variable } & Mean & $\begin{array}{c}\text { Standard } \\
\text { deviation }\end{array}$ & Minimum & Median & Maximum \\
\hline STICKYD1 & 0.178 & 1.765 & -4.516 & 0.175 & 4.881 \\
STICKYD2 & 0.224 & 1.011 & -3.006 & 0.135 & 3.996 \\
STICKY1 & 0.194 & 0.396 & 0 & 0 & 1 \\
STICKY2 & 0.368 & 0.482 & 0 & 0 & 1 \\
IC & 2.682 & 0.785 & 0 & 2.565 & 6.525 \\
GROUPD & 0.176 & 0.381 & 0.324 & 0 & 1 \\
SIZE & 1.634 & 2.214 & 0 & 0.002 & 16.891 \\
WORKER & 0.003 & 0.004 & -0.227 & 0.05 & 0.027 \\
CFO & 0.052 & 0.088 & 0 & 0 & 0.31 \\
SALES & 0.239 & 0.427 & 0 & 0.463 & 1 \\
LEV & 0.462 & 0.208 & & 3.632 \\
\hline Variab Definition
\end{tabular}

Variable Definitions:

STICKYD1 is cost stickiness dummy variable scaled by selling and administrative expenses. 1 if sticky is less than 0 , otherwise 0 .

STICKYD2 is cost stickiness dummy variable scaled by total cost. 1 if sticky is less than 0 , otherwise 0 .

STICKY1 is cost stickiness continuous variable scaled by selling and administrative expenses.

STICKY1 is cost stickiness continuous variable scaled by total cost.

IC is the natural logarithm of number of personnel of internal accounting

GROUPD is 1 if the enterprise belongs to a conglomerate, 0 otherwise

SIZE is the natural logarithm of (total asset of current term/total sales of current term)

WORKER is (number of employees*1,000,000/total sales of current term)

$\mathrm{CFO}$ is : (Cash flow from operating activities of the current term/ total asset of the current term)

SALES is 1 if sales of term $\mathrm{t}-1$ is decreased compared to term $\mathrm{t}-2,0$ otherwise

LEV is (total debt of the current term/total asset of the current term)

Table 3 shows the correlation among variables used in this study. First, STICKYD1 and STICKYD2 agreed with the hypothesis by showing a significant negative (-) correlation at $1 \%$ significance level with IC. As a result of examining the correlation among control variables, correlation between all control variables was less than 0.5 . 
Table 3. Pearson's correlation

\begin{tabular}{|c|c|c|c|c|c|c|c|c|}
\hline & STICKYD2 & IC & GROUPD & SIZE & WORKER & CFO & SALES & LEV \\
\hline STICKYD1 & $\begin{array}{c}0.489 \\
(<.0001)\end{array}$ & $\begin{array}{c}-0.214 \\
(<.0001)\end{array}$ & $\begin{array}{c}0.034 \\
(0.1343)\end{array}$ & $\begin{array}{c}-0.028 \\
(0.2206)\end{array}$ & $\begin{array}{c}0.015 \\
(0.5073)\end{array}$ & $\begin{array}{c}0.041 \\
(0.0734)\end{array}$ & $\begin{array}{c}-0.019 \\
(0.3973)\end{array}$ & $\begin{array}{l}-0.032 \\
(0.194)\end{array}$ \\
\hline STICKYD2 & & $\begin{array}{c}-0.133 \\
(<.0001)\end{array}$ & $\begin{array}{c}0.002 \\
(0.9256)\end{array}$ & $\begin{array}{c}-0.014 \\
(0.4292)\end{array}$ & $\begin{array}{c}0.015 \\
(0.4048)\end{array}$ & $\begin{array}{c}0.012 \\
(0.5052)\end{array}$ & $\begin{array}{c}0.013 \\
(0.4744)\end{array}$ & $\begin{array}{c}-0.05 \\
(0.0071)\end{array}$ \\
\hline $\mathrm{IC}$ & & & $\begin{array}{c}0.411 \\
(<.0001) \\
\end{array}$ & $\begin{array}{c}-0.004 \\
(0.8184) \\
\end{array}$ & $\begin{array}{c}-0.096 \\
(<.0001) \\
\end{array}$ & $\begin{array}{c}0.126 \\
(<.0001) \\
\end{array}$ & $\begin{array}{c}-0.073 \\
(<.0001) \\
\end{array}$ & $\begin{array}{c}0.106 \\
(<.0001) \\
\end{array}$ \\
\hline GROUPD & & & & $\begin{array}{c}-0.003 \\
(0.8193) \\
\end{array}$ & $\begin{array}{c}-0.084 \\
(<.0001) \\
\end{array}$ & $\begin{array}{c}0.07 \\
(<.0001)\end{array}$ & $\begin{array}{c}-0.034 \\
(0.0112) \\
\end{array}$ & $\begin{array}{c}0.151 \\
(<.0001)\end{array}$ \\
\hline SIZE & & & & & $\begin{array}{c}0.132 \\
(<.0001)\end{array}$ & $\begin{array}{c}-0.16 \\
(<.0001)\end{array}$ & $\begin{array}{c}0.122 \\
(<.0001)\end{array}$ & $\begin{array}{c}-0.095 \\
(<.0001)\end{array}$ \\
\hline WORKER & & & & & & $\begin{array}{c}0.048 \\
(0.0006)\end{array}$ & $\begin{array}{c}0.008 \\
(0.561)\end{array}$ & $\begin{array}{c}-0.049 \\
(0.0012)\end{array}$ \\
\hline $\mathrm{CFO}$ & & & & & & & $\begin{array}{c}-0.144 \\
(<.0001)\end{array}$ & $\begin{array}{c}-0.175 \\
(<.0001)\end{array}$ \\
\hline SALES & & & & & & & & $\begin{array}{c}-0.018 \\
(0.2384)\end{array}$ \\
\hline
\end{tabular}

\section{Multivariate Logistic Analysis}

Table 4 provides the results of logistic analysis carried out using STICKY dummy variable measured according to the method of Weiss (2010) as dependent variable in order to examine the effect of private debt on downward stickiness of cost. If increase in the number of personnel assigned to internal accounting control system shows increase in intensity of monitoring to result in efficient control of downward sticky cost behavior as proposed in the hypothesis of this study, interest factor $\beta 1$ of IC will show a significant negative (-) value.

As a result of analysis, estimated value of PRIVATE was -0.135 (Wald $\chi^{2}=3.8815$ ) when STICKYD1 is dependent variable and -0.137 (Wald $\chi^{2}=5.5729$ ) when STICKYD2 is dependent variable. It has significantly negative (-) influence on each dependent variable at 5\% significance level. Such result agrees with the hypothesis of this study that increased number of personnel assigned to internal accounting control system will increase the monitoring effect and reduce cost fixation of enterprises. 
Table 4: Effect of Internal Accounting Control System Personnel on Cost Stickiness

\begin{tabular}{|c|c|c|c|c|}
\hline \multirow{3}{*}{ Variables } & \multicolumn{4}{|c|}{ Dependent Variable } \\
\hline & \multicolumn{2}{|c|}{ STICKYD1 } & \multicolumn{2}{|c|}{$\begin{array}{l}\text { STICKYD2 } \\
\end{array}$} \\
\hline & Estimate & Wald $\chi^{2}$ & Estimate & Wald $\chi^{2}$ \\
\hline Intercept & -0.822 & $5.1887 * *$ & 0.871 & $7.6912 * * *$ \\
\hline IC & -0.135 & $3.8815 * *$ & -0.137 & $5.5729 * *$ \\
\hline GROUPD & 0.252 & $3.5058^{*}$ & 0.019 & 0.0284 \\
\hline SIZE & -0.04 & 0.5259 & -0.189 & $8.5529 * * *$ \\
\hline WORKER & 1.085 & 0.003 & -70.335 & $13.2764 * * *$ \\
\hline $\mathrm{CFO}$ & 0.565 & 0.797 & -1.106 & $4.0837 * *$ \\
\hline SALES & -0.203 & $2.8987^{*}$ & -0.136 & 1.8121 \\
\hline LEV & -0.588 & $4.7708 * *$ & -0.631 & $7.2184 * * *$ \\
\hline $\begin{array}{l}\text { Year Dummies } \\
\text { Industry Dummies }\end{array}$ & \multicolumn{2}{|c|}{$\begin{array}{l}\text { Included } \\
\text { Included }\end{array}$} & & \\
\hline Likelihood Ratio $\chi^{2}$ & \multicolumn{2}{|c|}{$51.7211 * * *$} & \multicolumn{2}{|c|}{$95.8274 * * *$} \\
\hline Pseudo $\mathrm{R}^{2}$ & \multicolumn{2}{|c|}{0.02} & \multicolumn{2}{|c|}{0.03} \\
\hline Sample Size & \multicolumn{2}{|c|}{2,532} & \multicolumn{2}{|c|}{2,532} \\
\hline
\end{tabular}

Notes: $* * *, * *$, and $*$ represent significance at the 1,5 , and 10 percent levels, respectively.

Variable Definitions:

STICKYD1 is cost stickiness dummy variable scaled by selling and administrative expenses. 1 if sticky is less than 0, otherwise 0.

STICKYD2 is cost stickiness dummy variable scaled by total cost. 1 if sticky is less than 0, otherwise 0.

STICKY1 is cost stickiness continuous variable scaled by selling and administrative expenses.

STICKY1 is cost stickiness continuous variable scaled by total cost.

IC is the natural logarithm of number of personnel of internal accounting

GROUPD is 1 if the enterprise belongs to a conglomerate, 0 otherwise

SIZE is the natural logarithm of (total asset of current term/total sales of current term)

WORKER is (number of employees $* 1,000,000 /$ total sales of current term)

CFO is : (Cash flow from operating activities of the current term/total asset of the current term)

SALES is 1 if sales of term $t-1$ is decreased compared to term $t-2,0$ otherwise

$L E V$ is (total debt of the current term/total asset of the current term)

\section{Downward Stickiness of Cost Measured as Continuous Variable(Additional Test 1)}

Hypothesis testing model of this study measured downward stickiness of cost as a dummy variable. In this section, STICKY1 and STICKY2 that measured downward stickiness of cost as a continuous variable are used as dependent variables to perform regression analysis for securing robustness of the study.

Table 5 shows the effect of variable IC for the number of human resources assigned to internal accounting control system on STICKY1 and STICKY2, the variables of downward cost stickiness measured as continuous variables. As a result of verification, when STICKY1 measured by selling and administrative expenses was dependent variable, the coefficient of IC for the number of human resources assigned to internal accounting control system was $-0.477(\mathrm{t}-\mathrm{value}=-6.37)$. When STICKY2 measured by total cost was dependent variable, the coefficient of IC was -0.152 (t-value $=-4.93$ ). It showed significantly negative (-) influence on dependent variables at $1 \%$ significance level. The results of $<$ Table $5>$ support robustness of the study results as they agree with the basic hypothesis testing results of this study. 
Table 5: Effect of Internal Accounting Control System Personnel on Cost Stickiness Measured as Continuous Variable

\begin{tabular}{|c|c|c|c|c|}
\hline \multirow{3}{*}{ Variables } & \multicolumn{4}{|c|}{ Dependent Variable } \\
\hline & \multicolumn{2}{|c|}{ STICKY1 } & \multicolumn{2}{|c|}{ STICKY2 } \\
\hline & Coeff. & t-value & Coeff. & t-value \\
\hline Intercept & 1.415 & $3.41 * * *$ & 0.794 & $4.78 * * *$ \\
\hline IC & -0.477 & $-6.37 * * *$ & -0.152 & $-4.93 * * *$ \\
\hline GROUPD & 0.582 & $3.75 * * *$ & 0.113 & $1.8^{*}$ \\
\hline SIZE & 0.008 & 0.14 & 0.036 & 1.23 \\
\hline WORKER & 12.475 & 0.52 & -5.671 & -0.5 \\
\hline $\mathrm{CFO}$ & 0.363 & 0.5 & -0.143 & -0.47 \\
\hline SALES & 0.042 & 0.31 & 0.021 & 0.39 \\
\hline LEV & -0.616 & $-1.97 * *$ & -0.291 & $-2.23 * *$ \\
\hline $\begin{array}{l}\text { Year Dummies } \\
\text { Industry Dummies }\end{array}$ & \multicolumn{2}{|c|}{$\begin{array}{l}\text { Included } \\
\text { Included }\end{array}$} & & \\
\hline F-value & \multicolumn{2}{|c|}{$3.00 * * *$} & \multicolumn{2}{|c|}{$2.81 * * *$} \\
\hline Adj. $\mathrm{R}^{2}$ & \multicolumn{2}{|c|}{0.04} & \multicolumn{2}{|c|}{0.02} \\
\hline Sample Size & \multicolumn{2}{|c|}{2,532} & \multicolumn{2}{|c|}{2,532} \\
\hline
\end{tabular}

Notes: $* * *, * *$, and $*$ represent significance at the 1,5 , and 10 percent levels, respectively.

STICKY1 is cost stickiness continuous variable scaled by selling and administrative expenses.

STICKY1 is cost stickiness continuous variable scaled by total cost.

IC is the natural logarithm of number of personnel of internal accounting

GROUPD is 1 if the enterprise belongs to a conglomerate, 0 otherwise

SIZE is the natural logarithm of (total asset of current term/total sales of current term)

WORKER is (number of employees*1,000,000/total sales of current term)

CFO is : (Cash flow from operating activities of the current term/ total asset of the current term)

SALES is 1 if sales of term $t-1$ is decreased compared to term $t-2,0$ otherwise

LEV is (total debt of the current term/total asset of the current term)

\section{IC Variable Controlled by Total Number of Executives and Employees (Additional Test 2)}

In this study, hypothesis was tested by measuring IC, the variable for internal accounting personnel, as a natural $\log$ value. Such measurement has a problem of not being able to account for the difference according to size of enterprise. Accordingly to secure robustness of this study, this section re-measures IC the variable for internal accounting personnel as a value divided by total number of executives and employees instead of natural $\log$ to perform logistic analysis.

Table 6 shows the effect of internal accounting control system personnel variable IC on dummy variables STICKYD1 and STICKYD2 of downward cost stickiness. As a result of verification, estimated value of IC, the number of human resources assigned to internal accounting control system, was -1.524 (Wald $\chi^{2}=2.82$ ) when STICKY1 measured by selling and administrative expenses was dependent variable. Estimated value of IC was 1.732 (Wald $\chi^{2}=6.06$ ) when STICKY2 measured by total cost was dependent variable. It showed significantly negative (-) influence on dependent variables at $10 \%$ and $5 \%$ significance levels, respectively. The results in $<$ Table $6>$ support robustness of the study results as they agree with the basic hypothesis testing results of this study. 
Table 6: Effect of Internal Accounting Control System Personnel on Cost Stickiness

\begin{tabular}{|c|c|c|c|c|}
\hline \multirow{3}{*}{ Variables } & \multicolumn{4}{|c|}{ Dependent Variable } \\
\hline & \multicolumn{2}{|c|}{ STICKYD1 } & \multicolumn{2}{|c|}{ STICKYD2 } \\
\hline & Estimate & Wald $\chi^{2}$ & Estimate & Wald $\chi^{2}$ \\
\hline Intercept & -1.047 & $10.0267 * * *$ & 0.606 & $4.4829 * *$ \\
\hline IC & -1.524 & $2.8285^{*}$ & -1.732 & $6.0619 * *$ \\
\hline GROUPD & 0.106 & 0.6961 & -0.135 & 1.4985 \\
\hline SIZE & -0.034 & 0.3582 & -0.167 & $6.5021 * *$ \\
\hline WORKER & 3.319 & 0.0276 & -69.43 & $12.6759 * * *$ \\
\hline $\mathrm{CFO}$ & 0.381 & 0.347 & -1.392 & $6.2508 * *$ \\
\hline SALES & -0.198 & 2.7037 & -0.124 & 1.4764 \\
\hline LEV & -0.656 & $5.7495 * *$ & -0.639 & $7.2151 * * *$ \\
\hline $\begin{array}{l}\text { Year Dummies } \\
\text { Industry Dummies }\end{array}$ & \multicolumn{2}{|c|}{$\begin{array}{l}\text { Included } \\
\text { Included }\end{array}$} & & \\
\hline Likelihood Ratio $\chi^{2}$ & \multicolumn{2}{|c|}{$52.26^{* * *}$} & \multicolumn{2}{|c|}{$94.44 * * *$} \\
\hline Pseudo $\mathrm{R}^{2}$ & \multicolumn{2}{|c|}{0.02} & \multicolumn{2}{|c|}{0.03} \\
\hline Sample Size & \multicolumn{2}{|c|}{2,532} & \multicolumn{2}{|c|}{2,532} \\
\hline
\end{tabular}

Notes: $* * * * *$, and $*$ represent significance at the 1,5 , and 10 percent levels, respectively.

STICKYD1 is cost stickiness dummy variable scaled by selling and administrative expenses. 1 if sticky is less than 0 , otherwise 0 .

STICKYD2 is cost stickiness dummy variable scaled by total cost. 1 if sticky is less than 0 , otherwise 0 .

STICKY1 is cost stickiness continuous variable scaled by selling and administrative expenses.

STICKY1 is cost stickiness continuous variable scaled by total cost.

IC is the natural logarithm of number of personnel of internal accounting

GROUPD is 1 if the enterprise belongs to a conglomerate, 0 otherwise

SIZE is the natural logarithm of (total asset of current term/total sales of current term)

WORKER is (number of employees*1,000,000/total sales of current term)

CFO is : (Cash flow from operating activities of the current term/ total asset of the current term)

SALES is 1 if sales of term $\mathrm{t}-1$ is decreased compared to term $\mathrm{t}-2,0$ otherwise

LEV is (total debt of the current term/total asset of the current term)

Importance of Personnel in Each Department Assigned to Internal Accounting Control System (Additional Test 3)

Revision of the form "operation report on internal accounting management system" in September 2002 came to require enterprises to publicly announce their ownership status of internal accounting control organization personnel and certified public accountants. Referring to the table provided in the part on measurement of personnel status for internal accounting control system, enterprises must publicly announce affiliated institution and department of human resources assigned to internal accounting. The department is classified into auditor (committee), board of directors, accounting department, capital operation department, electronic operation department and other relevant departments.

While auditor (committee) and board of directors perform the role of generally managing and reviewing internal accounting control system, accounting department, capital operation department and electronic operation department are actual departments that execute the procedure of internal control. Based on the operation report on internal accounting control system publicly announced by each enterprise, this study additionally analyzed the effect of importance of internal accounting personnel affiliated to accounting department (ACC_NUM), capital operation department (CAP_NUM) and electronic operation department (ELE_NUM) on downward stickiness. The results of additional analysis are shown in Table 7.

As a result of analysis, the coefficient of ACC_NUM was -7.152 (t-value=-10.47) and showed significantly negative (-) influence on dependent variable STICKY1 at 1\% significance level. CAP_NUM and ELE_NUM were not significant. In the verification result using STIKCY2 measured by total cost, the coefficient of ACC_NUM was -4.365 (t-value=-13.59) and showed significantly negative (-) influence on dependent variable STICKY2 at $1 \%$ significance level.

Such results suggest that ownership of sufficient accounting personnel to internally review financial statements is effective in monitoring downward stickiness in accounting departments that perform accounting works 
like equity method and deferred corporate tax and prepare for consolidated financial statements and cash flow statement.

Table 7: Effect of Internal Accounting Control System Personnel on Cost Stickiness

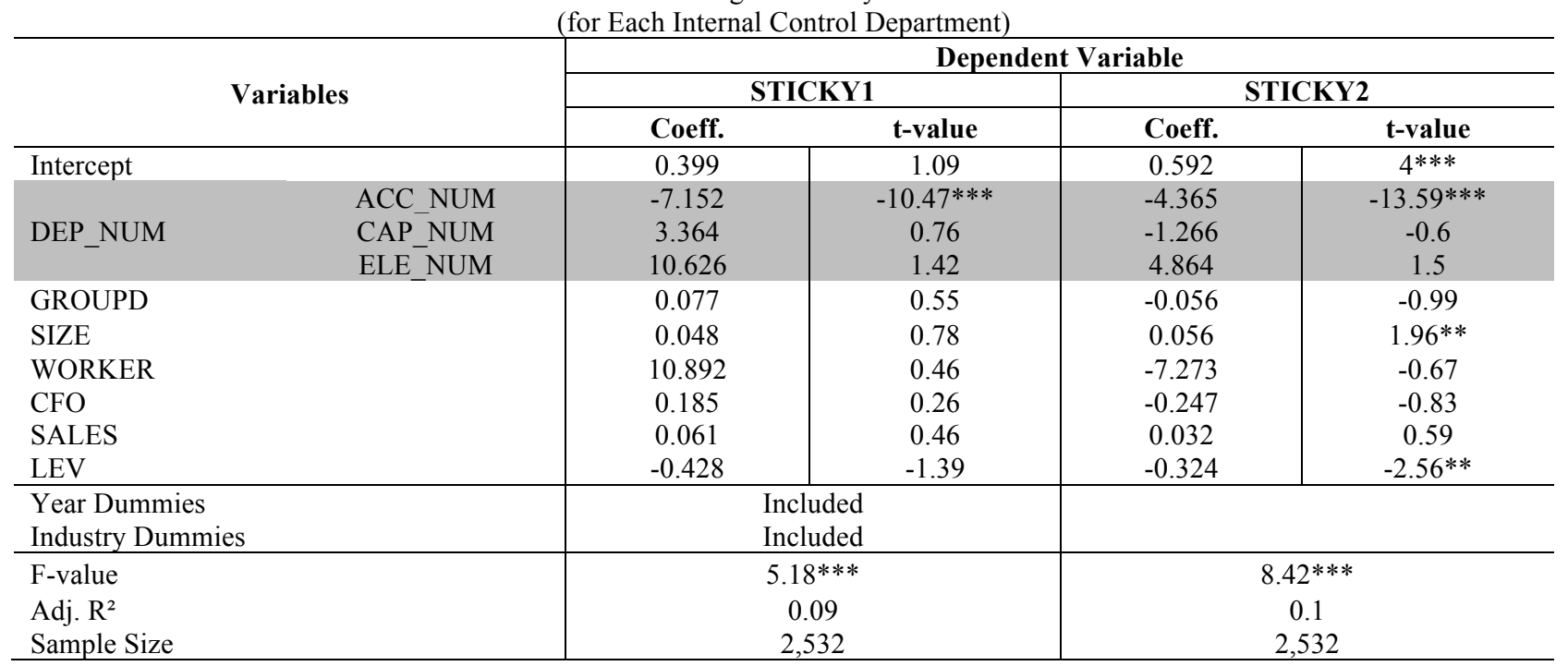

Notes: $* * * * *$, and $*$ represent significance at the 1,5 , and 10 percent levels, respectively.

STICKY1 is cost stickiness continuous variable scaled by selling and administrative expenses.

STICKY1 is cost stickiness continuous variable scaled by total cost.

dep_num $=$ the ratio of the number of internal accounting control personnel in each department

acc_num $=$ the ratio of the number of internal accounting control personnel in accounting department to the total number of employees

cap num $=$ the ratio of the number of internal accounting control personnel in finance department to the total number of employees

ele_num $=$ the ratio of the number of internal accounting control personnel in information technology and system department to the total number of employeesGROUPD is 1 if the enterprise belongs to a conglomerate, 0 otherwise

SIZE is the natural logarithm of (total asset of current term/total sales of current term)

WORKER is (number of employees*1,000,000/total sales of current term)

CFO is : (Cash flow from operating activities of the current term/ total asset of the current term)

SALES is 1 if sales of term $\mathrm{t}-1$ is decreased compared to term $\mathrm{t}-2,0$ otherwise

$\mathrm{LEV}$ is (total debt of the current term/total asset of the current term)

\section{SUMMARY AND CONCLUSION}

Ever since Anderson et al. (2003) defined asymmetric response of cost to increase and decrease in sales as 'sticky cost behavior', there had been many studies on downward stickiness of cost. When sales volume is reduced, entrepreneurs are required to decide whether to continue possessing surplus resources in preparation for future recovery in sales or to dispose resources and reacquire disposed resources later on (Anderson et al. 2003). Representative examples of adjustment cost include severance pay for employees being dismissed, cost for new recruitment, cost for training and cost to cope with reduced morale of remaining employees. An entrepreneur has an incentive to not reduce cost despite reduction in sales as to maintain one's status and utility.

Many subsequent studies reported occurrence of downward sticky cost behavior caused by the agency problem, and they emphasized the role of control system as a means to reduce the agency problem. Previous studies reported that downward stickiness of cost can be relaxed when there is an appropriate monitoring device to observe agency problems such as corporate governance structure. Accordingly, internal accounting control system was considered in this study as a monitor of the agency problems. In specific, effectiveness of internal accounting control system was examined by size of human resources that belong to the system, and the aim was to verify whether downward stickiness of cost differs according to size of human resources.

Internal accounting control system was implemented to improve and enhance reliability of financial and accounting information. Internal accounting control system must be effectively operated in order to satisfy such intent of implementation, and operation of internal accounting control system would depend on the personnel in charge of internal accounting. The Committee of Sponsoring Organizations (COSO) also recommends enterprises to 
support effective internal control by possessing sufficient number of human resources for internal control. In other words, when an enterprise possesses sufficient number of internal accounting personnel, it can show appropriate distribution of work and effective internal control based on timely review and monitoring of accounting functions. The authors of this study predicted that larger size of internal accounting control system personnel will result in relaxation of downward cost stickiness as pursuit of private benefit by entrepreneurs can be effectively controlled.

As a result of empirical analysis, larger size of personnel assigned to internal accounting control system was found to lessen downward stickiness of cost. Such result implies that the agency problem can be effectively controlled due to excellent monitoring efficiency when size of personnel in charge of internal accounting control system is large. As an additional verification, departments to which internal accounting personnel are affiliated were considered to examine the effect of internal accounting personnel in each department on downward stickiness of cost. The verification result showed that larger size of internal accounting personnel affiliated to accounting departments, which directly participate in preparation of financial statements, plays greater role of lessening downward stickiness of cost compared to other departments.

The results of this study are meaningful in that they expanded the scope of study conducted by Chen et al. (2012) on asymmetric behavior of cost. Chen et al. (2012) argued that since control systems of an enterprise affects decision making of the entrepreneur, control systems like corporate governance structure can affect asymmetry of cost. This study considered internal accounting control system as a controller and monitor. The results of this study verified that enterprises with greater investment on personnel in charge of internal accounting control system show relaxed downward stickiness of cost due to high intensity of monitoring.

\section{AUTHOR INFORMATION}

Soo-Joon Chae, Ph.D., Professor of Accounting, School of Business, Kangwon National University, 192-1 Hyojadong, Chuncheon, Gangwon-do, Korea. E-mail: sjchae@kangwon.ac.kr (First Author)

Kiwi Chung, Ph.D., Professor of School of Business at Yeungnam University, Gyeongbuk, S. Korea. E-mail: kwchung@ynu.ac.kr (Corresponding Author)

\section{REFERENCES}

Ahn, S. and W. Choi. (2009). The Role of Bank Monitoring in Corporate Governance: Evidence from Borrowers' Earnings Management Behavior. Journal of Banking and Finance. 33 : 425-434.

Anderson, M. C., R. D. Banker, and S. N. Janakiraman. (2003). Are Selling, General, and Administrative Costs 'Sticky'? Journal of Accounting Research. $41:$ 47-63.

Anderson, S., Lanen, W. (2007). Understanding Cost Management: What Can We Learn from the Evidence on 'Sticky Costs'? Working Paper. Univ. of Melbourne.

Ashbaugh-Skaife, H., D. Collins, and W. Kinney. (2007). The Discovery and Consequences of Internal Control Deficiencies Prior to SOX-mandated Audits. Journal of Accounting and Economics. 44 : 166-192.

Balakrishnan, R., M. J. Petersen, and N. S. Soderstrom. (2004). Does Capacity Utilization Affect the "Stickiness" of Cost? Journal of Accounting, Auditing and Finance. 19 : 283-299.

Calleja, K., M. Steliaros, and D. C. Thomas. (2006.) A Note on Cost Stickiness: Some International Comparisons. Management Accounting Research. 17 : 127-140.

Chen C. H, H. Lu, and T. Sougiannis. (2012). The Agency Problem, Corporate Governance, and the Asymmetrical Behavior of Selling, General, and Administrative Costs. Contemporary Accounting Research. 29 : 252-282.

Choi, J. H., S. Choi, C. Hogan and J. Lee. (2013). The Effect of Human Resource Investment in Internal Control on the Disclosure of Internal Control Weaknesses. AUDITING: A Journal of Practice \& Theory. November. 32:169-199.

Cooper, R. and R. Kaplan. (1998). The Design of Cost Management Systems: Text, Cases and Readings. 2nd Edition. Prentices Hall.

COSO(The Committee of Sponsoring Organizations). (2006). Internal Control, Integrated Framework: Guidance for Smaller Public Companies. Available at http://www.coso.org 
Doyle, J., W. Ge, and S. McVay. (2007a)'. Determinants of Weaknesses in Internal Control over Financial Reporting. Journal of Accounting and Economics. $44: 193-223$.

Doyle, J., W. Ge, and S. McVay. (2007b). Accruals Quality and Internal Control over Financial Reporting. The Accounting Review. 82 : 1141-1170.

Ge, W., and S. McVay. (2005). The Disclosure of Material Weaknesses in Internal Control after the Sarbanes-Oxley Act. Accounting Horizons. 19 : 137-158.

Krishnan, J. (2005). Audit Committee Quality and Internal Control: An Empirical Analysis. The Accounting Review. $80,649-675$.

Noreen, E. (1991). Conditions under Which Activity-Based Cost Systems Provide Relevant Costs. Journal of Management Accounting Research. 3 : 159-168.

Weiss, D. (2010). Cost Behavior and Analysts' Earnings Forecasts. The Accounting Review. 85 : 1441-1471. 